\title{
Subject Characteristics Category
}

National Cancer Institute

\section{Source}

National Cancer Institute. Subject Characteristics Category. NCI Thesaurus. Code C83396.

A classification of subject characteristics data. 